\title{
In vriendskap met Darwin in die Christelike ontwerp van 'n antropologie?
}

\begin{abstract}
Author:
Daniël P. Veldsman ${ }^{1}$

Affiliation:

${ }^{1}$ Department of Systematic

Theology and Christian

Ethics, University of Pretoria,

South Africa

\section{Note:}

Two contributions by

the author have been re-worked for the article. The first contribution is from the Expert Seminar (September 2011). The seminar is a collaborative project between the Departments of Dogmatics of the Faculty of Theology, University of Pretoria, and the Protestantse Universiteit, Utrecht, The Netherlands. The second contribution is a paper that was read at the third Neuroscience Day of the University of Pretoria (May 2012).
\end{abstract}

\section{Correspondence to:}

Danie Veldsman

Email:

danie.veldsman@up.ac.za

Postal address:

Department of Systematic Theology and Christian Ethics, University of Pretoria, Lynwood Road, Hatfield 0083, South Africa

Dates:

Received: 10 Dec. 2012

Accepted: 12 Apr. 2013

Published: 06 June 2013

How to cite this article:

Veldsman, D.P., 'In

vriendskap met Darwin in die Christelike ontwerp van 'n antropologie?', HTS Teologiese Studies/ Theological Studies 69(1), Art. \#1374, 10 pages. http://dx.doi.org/10.4102/ hts.v69i1.1374

\section{Read online:}

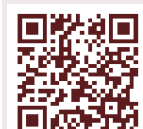

In friendship with Darwin in designing an anthropology from a Christian perspective? Best science and best theological reflection - the two belongs together for the sake of both. This is argued for in the exposition of the justification of friendship with Darwin (best science as evolutionary science) which is argumentatively connected from a Christian perspective to the praiseworthiness of God as creator (best theological reflection). Concretely, this implies making theologically sense of the important contemporary contribution of evolutionary biology on the origin of life and the descriptions of life. This endeavour necessitates a critical re-reading not only of Darwinian abuse and misperceptions but also of the larger historical context of the aforegoing scientific revolutions and their aftermath. Therefore, both discourses of abuse on the extreme spectrum of reflection on creation and life are critically addressed, namely creationism or Intelligent Design and bio-fundamentalism. As hermeneutical tool of discernment, the argument of evolutionary re-conceptualisation is unfolded as a distinction between an official story and alternative story to highlight not only the exciting implications of the latter but also especially as act of the de-domestication of our understanding of God as the praiseworthy God of creation.

\section{Inleiding}

In Christelike vriendskap met die negentiende-eeuse Britse naturalis ${ }^{1}$ Charles Darwin? Vir baie gelowiges mag die blote gedagte aan vriendskap met Darwin na godsdienstige laster klink! Maak sy voorstelling van die oorsprong van menslike lewe hom nie een van die grootste vyande van die Christelike geloof deurdat dit die bestaan van God en die doelmatigheid van die skepping per implikasie volledig ontken nie? Ontken hy nie eweneens die mens as skepping van God nie? Hoe kan daar dan enigsins van vriendskap met die vyand sprake wees? Is dit nie juis die kragtige boodskap wat die Skeppingsmuseum ${ }^{2}$ in Kentucky in die Verenigde State van Amerika (VSA) wil verkondig nie, naamlik dat daar geen sprake van 'n geheul met die evolusionêre vyand mag wees nie?

My bedoeling in hierdie artikel as bydrae tot teologiese nadenke oor 'n Christelike antropologie is om die drogbeelde oor Darwin (want dit is inderdaad wat baie van die heersende goedkoop opvattinge is) ${ }^{3}$ en die implikasies van sy naturalistiese bydrae te bespreek. Teenoor die Amerikaanse Skeppingsmuseum in Kentucky met al sy kunsmatige namaaksels staan die SuidAfrikaanse Wieg van die Mensdom ${ }^{4}$ met sy versameling fossiele as wetenskaplike getuienis (ten spyte van al die onklaar vrae wat vandag nog in baie navorsingskringe woed en ten minste erken word) van die menslike herkoms. Ek wil 'n teologiese saak daarvoor uitmaak dat dit vir gelowiges van grondige belang is om nie eenvoudig by die insigte van die evolusionêre biologie verby te lewe nie. Nie alleen kom die geloofwaardigheid van ons geloofsuitsprake oor die skepping en

1.In die negentiende eeu het navorsers wat ons vandag bioloë noem as naturaliste bekend gestaan

2.Die Skeppingsmuseum [The Creation Museum] is ' $n$ indrukwekkende museum wat in Mei 2007 naby Petersburg, Kentucky, in die Verenigde State van Amerika geopen is. In die museum vind ons nagemaakte voorstellinge van die sogenaamde oorsprong van die universum, die lewe en die mens vanuit 'n letterlike verstaan van die Genesis-verhaal. Die uitstallings in die museum verwerp biologiese evolusie volledig en gaan uit van die standpunt dat die aarde 6000 jaar gelede oor 'n tydperk van ses dae geskep is. Hierdie museum is al deur sowel wetenskaplike gemeenskappe as Christelike groepe daarvan beskuldig dat dit 'leuens bo feite' verkondig (so byvoorbeeld dat daar dinosourusse in Noag se ark was) aangesien dit die godsdienstige oortuiginge van 'n bepaalde groep gelowiges deur die
wanvoorstelling en miskenning van wetenskaplike insigte wil verkondig en verdedig (en dan nog boonop verdraai om hulle te pas!).

3.My verwysing na goedkoop opvattings het te make met veral drie ontwikkelings direk na Darwin wat Darwin se benadering vir hulle eie ideologiese oogmerke opgeëis en misbruik het. Hulle het Darwin se idees gebruik en voorgegee dat dit is wat Darwinisme impliseer. Die drie wat ek wil uitsonder is Hebert Spencer met sy Sosiale Darwinisme, Francis Galton met sy Eugenika (Eugenics) en Thomas Huxley - die sogenaamde 'Darwin's Bulldog' - met sy verkondiging van Darwinistiese Ateïsme. Hierop is vanuit baie kringe uiteenlopend en intens gereageer aangesien hierdie ontwikkelinge uiters negatiewe gevolge gehad het. Op verwarrende reaksionêre wyse is nou gemeen dat hierdie ontwikkelinge inderdaad is wat Darwinisme behels. Kyk veral Peters en Hewlett (2007:40 e.v.) se goeie uiteensetting hiervan asook hulle bespreking van latere verbandhoudende ontwikkelinge in Edward O. Wilson se Sosiobiologiese benadering en sy Evolusionêre Psigologie; vergelyk ook Antonites (2010:71 e.v.; 203 e.v.; 336 e.v.).

4.Die Wieg van die Mensdom [Cradle of Humankind] is ' $n$ wêrelderfenisgebied naby Krugersdorp in die Gauteng-provinsie in Suid-Afrika. Dit bestaan uit die Sterkfonteingrotte, Swartkrans, Kromdraai en die omliggende dele. Dit is een van die plekke waar die heel oudste hominied- of aapmensfossiele - tot soveel as 3.5 miljoen jaar oud - ter wêreld gevind is. Een van die beste voorbeelde is die fossiel met die bynaam mev. Ples (Australopithecus africanus), wat 2.3 miljoen jaar oud is, wat hier gevind is. Ander fossiele van uitgestorwe dier- en plantspesies is ook al hier gevind. 
menswees op die spel as ons die evolusionêre biologie beleef nie, maar ten diepste ook die prysenswaardigheid van die God wat ons as Skepper van die hemel en die aarde bely. Skepper van die hele hemel en aarde! In hierdie gesprek met die evolusionêre biologie is een van my uitgangspunte dus dat ek Darwin se bydrae ernstig neem. Ek bespreek eerstens kortliks wat ons onder Darwin se bydrae moet verstaan. Tweedens bespreek ek die eietydse bydrae van die evolusionêre biologie tot die gesprek en daarna fokus ek op hoe die uiteenlopende drogbeelde oor Darwin in 'n groter filosofies-historiese konteks van natuurwetenskaplike revolusies aangespreek behoort te word. Laastens vra ek 'n vraag wat ten diepste afstuur op die prysenswaardigheid, die aanbiddingswaardigheid van ons God wat ons as Skepper van die hemel en die aarde bely.

Reg aan die begin wil ek enersyds duidelik stel dat ek nie 'n benadering sal volg soos dié van die verskillende kreasionistiese bewegings ${ }^{5}$ wat op grond van 'n letterlike verstaan van die Bybelse boodskap oor al hulle opvattinge oor die skepping heel seker is en dan die natuurwetenskaplike bydraes in die lig daarvan beoordeel nie. ${ }^{6}$ Dit is doodgewoon intellektueel oneerlik en misleidend (so byvoorbeeld die Skeppingsmuseum). Hulle maak iets van die Bybel wat dit self nie is nie en wys dan natuurwetenskaplike standpunte op grond daarvan af. Hierdie oneerlike wyse van omgang met die Bybel hou vernietigende gevolge in vir die geloofwaardigheid van gelowiges se diepgesetelde belydenis oor geloof in 'n heilige God as skepper en vir ons verstaan van menswees. So ook wil ek die benadering wat as Intelligente Ontwerp (Intelligent Design) ${ }^{7}$ bekend staan, summier afwys aangesien dit glad nie ' $n$ wetenskaplike benadering is nie, maar 'n vooropgestelde religieuse standpunt wat onder die dekmantel van wetenskap aangebied word. Hierdie twee invloedryke strominge (Kreasioniste en Intelligente Ontwerp [IO]) laat albei in hulle wyse van omgaan met die Bybel toenemend sekulêre spore in ons samelewings. ${ }^{8}$ Is ons egter bereid om as gelowiges na die insigte van evolusionêre bioloë te luister, meen ek dat juis God se aanbiddingswaardigheid, God se prysenswaardigheid en ons belydenis van God as Skepper op ' $n$ heel verrassende nuwe wyse as aangrypende geloofsbelydenis vanuit die Bybelse boodskap na vore kom. Dit kom na vore as belydenis oor 'n heilige God wat nog veel groter en onpeilbaar dieper is as wat ons enigsins sou kon dink, maar wat terselfdertyd ook 'n lewensbetrokke God is

\section{Daar is baie verskillende groeperinge van Kreasioniste waarvan die volgende drie waarskynlik die mees prominente is: die Bybelse Kreasioniste, die Wetenskaplike Kreasioniste en die Progressiewe Kreasioniste. Vir'n baie duidelike uiteensetting oor wat elkeen van hierdie groeperinge inhou en elkeen se besondere beklemtoninge kyk na Peters en Hewlett (2007:57 e.v.; vgl. Cunningham 2010; Antonites 2010:261 e.v.; 550 e.v.). Kyk ook na Montgomery (2012) se goeie en kort historiese uiteensetting oor die ontwikkeling van die Kreasionisme.}

6.Ek sou hulle werkswyse in die lig van die sogenaamde beskuldiging oor die 'vermiste skakels' kortliks so wou saamvat: Dit is om die afwesigheid van afdoende bewyse summier in ' $n$ volledige bewys van afwesigheid om te draai, dit wil sê, om die ontbrekende getuienis te misbruik om evolusie te ontken.

7.Kyk onder andere na die volgende bronne vir baie goeie en deeglike besprekings hieroor: Van de Beek (2005); Cunningham (2010); Southgate (2008); Peters en Hewlett (2007:77 e.v.).

8.Die 'sekulêre spore' waarna ek hier verwys, is die vervreemding wat dikwels as gevolg van ongeloofwaardige (kerklike) uitsprake oor menswees en die skepping by ingeligte mense teenoor die kerk en haar boodskap ontstaan. wat nie in ons domestiserende grepe ${ }^{9}$ vasgevang kan word nie. Daarvan kan 'n vriendskapsluiting met Darwin ons juis verdiepend bevry!10

Ek wil ook andersyds ten sterkste protesteer teen eietydse bio-fundamentaliste ${ }^{11}$ wat met hulle ongegronde aansprake vanuit die evolusieteorie, naamlik dat God nie sou bestaan nie, die opwindende en toenemend verruimende en opbouende gesprek tussen die teologie en die natuurwetenskappe groot skade aandoen. Evolusie 'bewys' volgens hulle uiteindelik vir eens en vir altyd dat God nie bestaan nie. Op flagrante wyse weerspreek hulle hul eie verering van die natuurwetenskaplike empiriese metodologie! So asof empiriese waarneming as ' $n$ besondere metodologiese wyse (en weliswaar die suksesvolste moet ek byvoeg!) om kennend met die werklikheid om te gaan sigself as empiriese waarneming wetenskapsfilosofies kan begrond. ${ }^{12}$ Dit kan doodgewoon nie, maar hierdie invloedryke biofundamentaliste verkondig luidkeels dat dit kan. As dit so sou kon, is die tyd van wetenskaplike wonderwerke beslis nie verby nie.

In kort dus: Ek meen dat ons die beste teologiese insigte en die beste natuurwetenskaplike insigte bymekaar moet uitbring. Anders gesê: My doel is om die Woord van God en die woordelose skepping van God saam met natuurwetenskaplik-evolusionêre ${ }^{13}$ insigte oor die skepping en lewe ernstig te neem. Die Suid-Afrikaanse wiskundige George Ellis (2006:3) stel dit kort en saaklik: 'The science and religion dialogue provides essential benefits from religion to science and from science to religion - provided we reinforce the openminded, nonfundamentalist tendencies on both sides.' Hierdie 'beide kante' verwoord die Amerikaanse teoloog Ted Peters (2007:viii) as 'the best science and our best thinking about God' en die twee hoort volgens hom saam! Voeg hierby die woorde van die Suid-Afrikaanse teoloog van Princeton (VSA), Wentzel van Huyssteen (2011):

Alleen wanneer ons die verskillende perspektiewe en verklaringsbeginsels van onderskeidelik teologie en wetenskap begryp, kan ons die resultate van die twee dissiplines

9.Na die begrip 'domestiserende grepe' kom ek in die slotgedeelte van die artikel terug.

10.Met die sinsnede 'vriendskapsluiting' bedoel ek eenvoudig dat die vyandiggesinde drogbeelde van wat die Darwinisme alles volgens Darwin se teenstanders sou impliseer, krities bespreek en weerlê moet word.

11. Hierdie persone wat ek as bio-fundamentaliste beskrywe, word egter ook met baie ander begrippe benoem, soos ontologiese materialiste, reduksioniste, sekulêre humaniste, Ultra-Darwiniste. Dis nogal verwarrende begrippe aangesien dit uiteenlopende benaderingswyses (biologies, filosofies) sonder onderskeiding saam uiteenlopende benaderingswyses (biologies, filosofies) sonder onderskeiding saam andere bioloë en filosowe insluit. Vier van die heel bekendste en invloedrykste persone wat hiervan deel uitmaak is die Britse bioloog Richard Dawkins, die persone wat hiervan deel uitmaak is die Britse bioloog Richard Dawkins, die
Amerikaanse filosowe Daniel Dennett en Sam Harris en die Brits-Amerikaanse joernalis Christopher Hitchens (saam ook bekend as die Vier Ruiters - 'the Four Horsemen' van die 'Nuwe Ateïsme')

12.Dit is dalk nodig om hierdie stelling beter te verduidelik. Dit beteken eenvoudig dat hierdie bio-fundamentaliste aanvoer dat die enigste wyse om tot die waarheid te kom deur die empiriese metodologie van waarneming en eksperimentering is. Die waarheid kan dus uiteindelik so bewys word. Hierdie wetenskaplikes kan egter nie hierdie oortuiging - as wetenskapsfilosofiese standpuntinname - deur hulle eie metode regverdig of bewys dat dit die enigste wyse is om tot die waarheid eie metode regverdig of bewys dat dit die enigste wyse is om tot die warheid te kom nie. So verteenwoordig hulle standpuntinname oor die waarheidsgehalte van ons kenuitsprake ' $n$ eksklusiewe aanspraak wat dus die karakter van 'n enigste aanvaarbare wyse is om tot kenuitsprake te kom wat as waarheid kan geld.

13. Die woord evolusie kom van die Latynse evolvere wat letterlik beteken: om uit te rol, om oop te rol. 
geloofwaardig met mekaar versoen ... In die hoofstroom teologie-en-wetenskapsdebat van vandag is die opinie feitlik eenparig dat God sy doelstellinge deur die natuurlike prosesse van ewolusie bereik. (bl. 120-121)

Ook die Suid-Afrikaanse teoloog Klaus Nürnberger (2011) eggo beskrywend hierdie oortuiging op die voorblad van sy onlangse publikasie Regaining sanity for the earth met die woorde: 'Why science needs best faith to be responsible; why faith needs best science to be credible.' Ek deel hierdie oortuiginge omdat dit nie alleen die volheid van menswees en die rol van waardes in ons lewens verdiep nie, maar veral die geloofwaardigheid van ons geloofsuitsprake oor God as skepper versterk. ${ }^{14}$ Vervolgens bied ek eers 'n kort verwysing na die uiteenlopende reaksies op die evolusieteorie en dan spesifiek ' $n$ bespreking oor die grondige rol van die evolusionêre biologie.

\section{Darwin as vriend}

Man may be excused for feeling some pride at having risen, though not through his own exertions, to the very summit of the organic scale ... We must however acknowledge, as it seems to me, that man with all his noble qualities, with sympathy which feels for the most debased, with benevolence which extent not only to other men, but to the humblest living creatures, with his godlike intellect which penetrates into the movement and constitutions of the solar system - with all these exalted powers - man still bears in his bodily frame the indelible stamp of his lowly origin. (Darwin 1871:geen bladsy)

Darwin $\neq$ evolusie nie $!^{15}$ Hy het absoluut niks geweet van gene nie. Dit is eerder Darwin + Mendell ${ }^{16}+$ Human Genome Project $(1995-2003)^{17}=$ Darwinisme! Charles Robert Darwin (1809-1882) het wel in sy On the Origin of Species ([1859] 1884) en Descent of Man (1871) die grondslag vir die evolusionêre benaderingswyse tot die oorsprong van lewe gelê. ${ }^{18}$ Die

14.Ek deel hierdie oortuiginge in die gees van die woorde van Pous Johannes Paulus II wat Cunningham (2010:284) aanhaal: 'Science can purify religion from error and superstition; religion can purify science from idolatry and false absolutes. Each can
draw the other into a wider world; a world in which both can flourish.' Hierdie draw the other into a wider world; a world in which both can flourish.' Hierdie
'flourish' stel George Ellis (2006:5) mooi: '[T]he science and religion debate can 'flourish' stel George Ellis (2006:5) mooi: '[T]he science and religion debate can be important in emphasizing the full dimension of humanity, and in particular the crucial role of value systems that cannot be derived from science alone. Thus, apart
from its role in deepening the understanding of religious faith in important ways, from its role in deepening the understanding of religious faith in important ways,
it can be an important integrative factor helping all humanity in the way we see it can be an important integrative factor helping all humanity in the way we see
ourselves and the universe in which we live, affecting our quality of life in a crucial way. It helps us be fully human.

15. Hierdie kort stelling: 'Darwin $\neq$ evolusie' is oop vir misverstand. Enersyds kan Darwin met reg die grondlegger van die moderne evolusieteorie genoem word. Die verdere ontwikkelings in die evolusionêre biologie en genetika bou voort op sy werk. Die stelling wil net beklemtoon dat nog verdere ingrypende ontwikkeling na Darwin plaasgevind het. Andersyds moet ingedagte gehou word dat Darwin beslis nie die eerste een was wat met die idee van evolusie vorendag gekom het nie. Hierdie eer kom die Antieke Griek to en by name Anaximander. Kyk veral na die goeie uiteensetting van Antonites (2010:2 e.v.) hieroor.

16.Gregor Mendel (1822-1884) word die vader van genetika genoem. Hierdie TsjeggiesOostenrykse monnik het in sy vrye tyd met ertjieplante geëksperimenteer. Deur sy ertjie-eksperimente het hy verskeie oorerwingspatrone in plante opgemerk wat as Mendel se wette geformuleer is. Dit het uiteindelik die grondslag vir genetiese navorsing gevorm.

17.Die Human Genome Project is 'n Amerikaanse navorsingsprojek wat in 1990 onderneem is en tot 2003 geduur het. Die primêre navorsingsfokus was die bepaling van die opeenvolging of samestelling ('sequence') van die chemiese basispare waaruit DNS bestaan, dit wil sê, om die genetiese samestelling van die menslike spesie te verstaan.

18.Vir ' $n$ baie goeie en kort oorsig oor Darwin se lewe en die filosofiese onderbou van sy benadering, kyk na Southgate (2008), Antonites (2010:1 e.v.) en Cunningham (2010). Interessant is die biografiese verwysing na Darwin se aanvanklike poging om medies te studeer, maar dat die bloed tydens operasies en amputasies hom so onthuts het dat hy toe eerder teologie gaan studeer het. In dié verband merk Antonites (2010:1) tong in die kies op: '[W]e have to thank Darwin's fear of blood for the theory of evolution!' reaksie op sy ontwerp was intens en baie uiteenlopend. Dit het gewissel vanaf volledige verwerping en beskuldigings van ateïsme ${ }^{19}$ aan die een kant van die spektrum tot by aanvaarding aan die ander kant van die spektrum. Aan die aanvaardingskant is daar wel uiteenlopende wyses oor hoe Darwinisme ondersteun word, wat ek kortweg soos volg wil omskryf:

- Volledige aanvaarding: 'n Voorbeeld hiervan is die sogenaamde bio-fundamentaliste (kyk ook na voetnota 13 wat na die verwarrende saamgroepeer van uiteenlopende benaderinge verwys) wat eintlik 'n fundamentalistiese lees van Darwin is. ${ }^{20}$ Hiervan is die 'New Atheist' beweging - soos Dennett, Dawkins en Hitchens - van die bekendste verteenwoordigers. Ek noem een voorbeeld om hierdie besondere tipe 'fundamentalisme' duidelik te maak. In sy Darwin's dangerous idea (1995) voer die Amerikaanse filosoof Daniel Dennett aan dat daar na Darwin geen goeie bestaansrede (in die sin van doelmatigheid) vir ons universum is nie. Meer nog: Dit verpletter enige heilige oortuiging dat die lewe en menslike bestaan van ewigheid af beplan is! In kort: Die wetenskap het gewen, religie het verloor. En Dennett se entoesiastiese ateïstiese vriend is natuurlik die Britse bioloog Dawkins wat in 'n groot aantal publikasies (soos The Selfish Gene, The God Delusion) oor die afgelope 20 jaar evolusie ten sterkste ondersteun en dan boonop aanvoer dat ateïsme sy sterkste intellektuele regverdiging nog ooit in Darwin gevind het.

- Gekwalifiseerde aanvaarding: Ek noem slegs twee Christelike voorbeelde wat in ' $n$ interessante opposisie teenoor mekaar staan, naamlik voorstanders van Intelligente Ontwerp (IO) (soos die Amerikaanse filosoof Michael Behe in sy Darwin's Black Box en die Amerikaanse teoloog William Dembski in sy No Free Lunch) en teologiesevolusionêre benaderinge (soos die Amerikaanse teoloog John Haught in sy God after Darwin ) wat op hulle beurt weer IO volledig verwerp. ${ }^{21}$

Ek sluit myself in by laasgenoemde groep wat 'n teologiesevolusionêre benadering voorstaan (en ook IO verwerp), en ek beskou my ook deel van die groep wat in 'n gekwalifiseerde waardering Darwin selfs 'as vriend' van die Christendom bestempel. Hierin sluit ek by Southgate (2008) aan in sy verwysing na die opmerking van Aubrey Moore:

19. Hierdie ateïstiese standpunt is sterk aangevuur deur opmerkinge soos dié van die bioloog David Hull. Southgate (2008:7) verwys daarna dat Hull ná Darwin se die bioloog David Hull. Southgate (2008.7) verwys daarna dat Hull ná Darwin se reis na die Galapagos-eilande en sy bevindinge daar die volgende vraag geste het: 'What kind of God can one infer from the sort of phenomena epitomised by the species on Darwin's Galapagos Islands? The evolutionary process is rife with happenstance, contingency, incredible waste, death, pain, and horro .. Whatever the God implied by evolutionary theory and the data of natura selection may be like, he is not the Protestant God of waste not, want not. He is also not the loving God who cares about his productions. He is not even the awful God pictured in the Book of Job. The God of the Galapagos is careless, wasteful, indifferent, almost diabolical. He is certainly not the sort of God to whom anyone would be inclined to pray.

20.Kyk na Darwin's pious idea deur Cunningham (2010) waarin hierdie beweging in besonderhede bespreek word.

21.Die Nederlandse teoloog Bram van de Beek (2005) bespreek IO op 'n baie deeglike wyse en verwerp dit uiteindelik met die lydingsvraag as primêre teologiese vraag as teenargument. Van de Beek neem nie spesifiek die teologie-wetenskap diskoers as raamwerk vir sy verwerping van IO nie. Vir'n kritiese bespreking van sy standpunt, kyk na Veldsman (2012a). Kyk ook na Antonites (2010:570 e.v.) se goeie standpunt, kyk na Veldsman (2012a). Kyk ook na Antonites (2010:570 e.v.) se goeie
uiteensetting alhoewel William Dembski foutiewelik in sy bespreking as Demski uiteensetting alh
aangedui word! 
The one absolutely impossible conception of God, in the present day, is that which represents him as an occasional visitor. Science has pushed the deist's God further and further away, and at the moment when it seemed as if he would be thrust out altogether Darwinism appeared, and, under the disguise of a foe, did the work of a friend. It has conferred upon philosophy and religion an inestimable benefit, by showing us that we must choose between two alternatives. Either God is everywhere present in nature, or he is nowhere. (bl. 10-11)

Hierdie 'werk as vriend' is die fokus van my uiteensetting. Inderdaad is dit die radikale implikasie van Southgate se stelling dat '(e)ither God is everywhere present in nature, or he is nowhere' waarvan hier werk gemaak moet word. Voordat die implikasie hiervan duideliker uitgespel word, is dit egter nodig om kortliks te omskrywe wat die Darwinisme behels.

Alle lewe het volgens Darwin uit'n enkele voorouer ontstaan. Deur natuurlike seleksie het die wyd uiteenlopende variasies en unieke nuwe spesies soos ons dit vandag ken deur die blinde noodlot tot stand gekom. Dit het oor eeue heen gebeur op grond van die aanpassings wat in hulle spesifieke natuurlike omgewing deur spesies gemaak is en waarvoor die beginsel van die oorlewing van die geskikste ${ }^{22}$ as 'aanpasbaarheid' en nie die sterkste nie!) gegeld het. Vanuit hierdie eeuelange evolusionêre proses het uiteindelik ook die mens ontstaan.

Darwin se teoretiese voorstel word vandag volledig as uitgangspunt geneem in die daaropvolgende ontwikkelinge wat ons in 'n kort oorsig oor die evolusionêre biologie sou kon saamvat. Vervolgens kyk ek hierna.

\section{Evolusionêre biologie}

Sedert die wending van die twintigste eeu het hierdie navorsingsveld ' $n$ ongekende bloeitydperk beleef! Vir baie navorsers is die biologie vandag in die een-en-twintigste eeu die natuurwetenskaplike vakgebied by uitnemendheid met 55 vertakkinge vanaf Aerobiologie tot Zoologie. ${ }^{23}$ As natuurwetenskaplike vakgebied fokus dit op die bestudering van die lewe en lewende organismes. Daar is vyf beginsels wat vir die moderne biologie as fundamentele aksiomas geld, te wete dat die sel die basiese eenheid van lewe is, dat nuwe spesies en oorgeërfde karaktertrekke die produk van evolusie is, dat gene die basiese eenheid van oorerwing is, dat 'n organisme sy of haar interne omgewing reguleer ten einde 'n stabiele en konstante toestand te verseker en dat lewende organismes energie verbruik en omvorm (transformeer). Die evolusionêre biologie is een van die subdissiplines van die biologie. As navorsingsveld fokus dit op die bestudering van die evolusionêre prosesse wat vir die diversiteit van lewe op

22. Hierdie uitdrukking is deur Hebert Spencer gemunt en later deur Darwin oorgeneem. Lees ook Antonites (2010:91) hiermee saam: 'Natural selection selects the fittest, but it also selects a good adaptation repeatedly, even in different and unrelated species. This is called convergence. This is one of the most remarkable, wonderful, and marvellous feats of evolution on earth and the universe.'

23.Antonites (2010:xi) stel dit soos volg: 'Just as the theory of relativity and quantum theory are now widely accepted in physics, the theory of evolution in the biological sciences has come to be regarded as the current dominant basic and most widely accepted theory or paradigm.' En enkele paragrawe later: 'The theory of evolution accepted theory or paradigm. 'En enkele paragrawe later: 'The theory of evolution
today is widely regarded as one of the greatest scientific endeavors and advances of all times' (Antonites 2010:xi). die aarde verantwoordelik is, dit wil sê, die oorsprong en herkoms van spesies. Kim Sterelny, die Australiese filosoof van die Research School of Social Sciences aan die Australian National University en Victoria University of Wellington stel onomwonde in sy Philosophy of Evolutionary Thought dat die ontwikkeling van die evolusionêre biologie sedert 1858 een van die merkwaardige intellektuele ontwikkelings van die wetenskap is (Sterelny 2009:313). Voeg hierby die opmerking van die Russies-Amerikaanse bioloog Theodosius Dobzhansky dat niks in die biologie meer sin maak as dit nie vanuit 'n evolusionêre perspektief beskou word nie ${ }^{24}$ en die onmisbare belang van biologiese navorsing wat vanuit 'n evolusionêre perspektief beoefen word, word oortuigend bevestig. Baie uiteenlopende velde word tans vanuit hierdie perspektief nagevors, maar veral vier navorsingsfokusse kan aangedui word: eerstens, spesievorming en seksuele reproduksie; tweedens, die allesbegrondende evolusionêre vraag, naamlik 'wat het gebeur en wanneer?'; derdens, die genetiese argitektuur van aanpassing en spesievorming; en, vierdens, genetiese kragte soos natuurlike seleksie en seksuele seleksie.

Vanuit hierdie baie kursoriese oorsig oor die biologie as vakdissipline wil ek net die fundamentele stelling maak: Die biologie is by uitstek die natuurwetenskaplike vakgebied wat aan ons die basiese inligting oor die lewe, oor die oorsprong daarvan en oor diversiteit gee. Geen ander natuurwetenskap het op so 'n intensiewe en suksesvolle wyse ons verstaan van die boom van lewe ('Tree of Life') en ons genetiese samestelling verdiep en verbeed nie en ons met die bestryding van siektes en epidemies, mediese afwykings en gebreke en die industriële produksie van biochemiese stowwe en baie ander ontwikkelings gehelp nie! As ek die bioloog egter te midde van die gewoel en gewerskaf in die laboratorium sou vra: 'Verskoon my, maar ek wil graag weet: "Wat is lewe?"', sou ek die verrassende antwoord kry dat daar geen eenduidige beskrywing van die lewe is nie. En terwyl ek nog verbaas staan, kom 'n magdom vrae spontaan by my op. Sal ons ooit die enkele relevante teoretiese raamwerk vir 'n definisie van lewe kry? Wanneer sal ons weet presies hoe lewe in die eerste plek ontstaan het en hoe dit gelyk het? Wanneer sal ons weet wat of wie neem besluite in die sel, en hoe presies dit gebeur? En seksuele reproduksie: Waar en hoe het dit ontwikkel? Hoekom het evolusie dierelewe ontwikkel? Wanneer sal ons presies weet wat bewussyn is? Eindelose vrae. En dan is die verdere verrassing die bioloë se uiteenlopende antwoorde op hierdie en ander vrae heel dikwels in metaforiese terme of met ' $n$ sterk eksistensiële kleur gegee word. ${ }^{25}$ Die sel is 'n agent of redakteur, of die sel is selfsugtig, of die evolusionêre proses verloop as ' $n$ besluitnemingsproses! Die verrassende is: Daar is 'n vloeibaarheid, 'n onbepaalde grenslyn tussen die konkrete en metaforiese gebruik van die term lewe.

24. Dit was ook die titel van sy bekende artikel "Nothing in biology makes sense except in the light of evolution' in die American Biology Teacher (1973).

25.Om watter rede is hierdie metaforiese taalgebruik of eksistensiële inkleuring in die natuurwetenskaplike konteks vir my verrassend benewens die vloeibaarheid in die beskrywing van lewe? Omdat dit nie alleen die subjektiewe interpretatiewe moment ten aansien van werklikheidsverstaan duidelik voorop laat staan nie, maar dikwels ook iets van die ideologiese karakter van ons werklikheidsverstaan laat deurskemer. Kyk as voorbeeld na die opmerking net hierna in my argument oor die deurskemer. Kyk as voorbeeld na die opmerking net hierna in my argument oor die
Britse sosioloog Bronislaw Szerszynski (2012) wat gesê het: Om lewe te sê, is om interpretasies te verwelkom! 
$\mathrm{Al}$ is die biologie 'n uiters suksesvolle wetenskap, ontwyk dit waarop dit berus, naamlik die bios (die Griekse woord vir lewe) enige finale natuurwetenskaplike vaspenning in afdoende definisies. Die Latynse woord vir lewe is vita. Ook met hierdie begrip meen ons dat ons vita in 'n biografie materialiseer en daarom stel ons graag 'n noukeurige curriculum vitae saam. Al die moeite, terwyl ons weet: Dit sê nie alles nie. Dit sê veels te min. Dit reflekteer eintlik maar net ons vita activa. Wat van ons vita contemplativa? Die punt is: Wie gaan lewe afdoende en volledig definieer? Wie gaan dit waag, veral nou waar feitlik elke omskrywing van lewe deur teenvoorstelle geproblematiseer of gevalsifiseer kan word. ${ }^{26}$ In ' $n$ heel onlangse ongepubliseerde voordrag met die titel 'Life in the open air' het die Britse sosioloog Bronislaw Szerszynski in April 2012 in Tartu in Estland die volgende opmerking gemaak:

To say Life, is to invite interpretations; To say Life is to ask which knowledge interest lies behind the question; To say Life is to set up boundaries: life-non-life; biology-physics; animateinanimate; life-death; life-survival Szerszynski.

Ten minste kan ons vanuit 'n filosofiese perspektief saamstem dat menslike lewe veel meer as net 'n molekulêre masjien sonder enige doel is. Dat lewe meer is as blote biologiese bestaan. Vra ons vrae oor 'n goeie lewe, dan praat ons oor die etiek; praat ons oor skoonheid in die lewe, praat ons oor estetika; soek ons na antwoorde oor die vraag na die doel van lewe, dan praat ons oor teleologie. So kan ons aangaan. Daar is meer op die spel. Betekenis staan op die spel. En van hierdie 'spelling' van die (lewens)spel maak onsself deel uit. Op geen wyse is ons as menslike lewe - wat dit wil interpreteer en verstaan - bloot toeskouers van lewe nie. Nee, ons is aktiewe en gevoelsmatige interpreteerders van lewe as deelnemers aan lewe self. Hierin sluit ek aan by die Duitse medikus Viktor von Weizsaecker wat by geleentheid gesê het dat navorsing oor lewende wesens net vanuit deelname moontlik is. En om interpretatief aan lewe deel te neem, is om vanuit ' $n$ bepaalde lewens- en wêreldbeskouing 'n deelnemer te wees. Dit maak elkeen van ons se betekenisraamwerk (of paradigma) uit van waaruit of waarmee ons die vraag na die sin van die lewe beantwoord. Kortweg gesê: Dit is 'n aprioriese karaktertrek van menswees. En hierdie singewende karaktertrek van menswees sien ons duidelik in die paradigmaverskuiwings voor en na Darwin.

Ten einde die ingrypende paradigmaverskuiwing wat Darwin se bydrae teweeggebring het, skerper raak te sien, is dit na my oordeel nodig om sy bydrae in die historiesfilosofiese konteks van wetenskaplike revolusies te plaas wat hom voorafgegaan en na hom gekom het. Dit verbreed en verdiep die antropologie waarmee ons wil werk. Wat op 'n insiggewende wyse uit hierdie oorsig sal blyk, is dat ons sogenaamde 'amptelike stories' ${ }^{27}$ (ook genoem: populêre

26.Lewe word in die literatuur op die mees uiteenlopende wyses beskrywe metabolisme, groei, reproduksie, reaksie op eksterne stimuli, aanpassing by verandenge in die omgewing, een of ander vorm van kommunikasie wat aanleiding gee tot een of ander vorm van koordinasie - alles poginge om

27.My gebruik van die ongewone begrip 'stories' in hierdie konteks van natuurwetenskaplike denke is juis om die interpreterende, die kontekstuele en historiese dimensies van ons standpuntinnames - ook in die natuurwetenskappe! - te beklemtoon. standpunte) en 'alternatiewe stories' kry. Amptelike stories verteenwoordig heel duidelik nie die beste wetenskap nie, terwyl alternatiewe stories - wat juis die beste wetenskap verteenwoordig - dikwels nie luid verkondig word nie!

\section{Amptelike versus alternatiewe stories}

Ek sou speels wou vra: Was 3.7 biljoen jaar se kosmiesevolusionêre ontwikkeling nou regtig nodig net om 'n persoon met die besondere kwaliteite van Nelson Mandela op te lewer? My gekwalifiseerde antwoord is ja en nee. ${ }^{28} \mathrm{Ja}-$ want vanuit hierdie bevestiging word die onmisbare belang van doelmatigheid, waardes en menslike betekenisvolheid beklemtoon. Nee - want ook die blote bevestiging sê nog (reduksionisties) te min. Indien hierdie vraag gestel word binne die konteks van die revolusies in lewens- en wêreldbeskouings wat deur ingrypende wetenskaplike verskuiwinge teweeggebring is, word beide ja en nee op 'n radikale wyse diep revisionêr geprofileer. Neem as voorbeeld net my invalshoek by die invloed op teologiese nadenke. Sou die teologiese nadenke as koningin van die wetenskappe veral vanaf die laat Middeleeue die sterk karakter gedra het van 'om alles te verduidelik' en sodoende die indruk geskep het dat die teologiese nadenke sigself in 'n posisie bevind waar sy oor ' $n$ monopolie beskik om te beslis wat as kennis sou geld en wat nie (en wat dus aanvaarbaar sou wees al dan nie), sou hierdie bevoorregte 'kenposisie' met die wetenskaplike revolusies grondig verander het. Die moderne natuurwetenskaplike denke het sigself nou met groot materialistiese gemak in hierdie posisie aangestel. ${ }^{29}$ Gevolglik is die teologies-filosofiese nadenke deur die gang van die wetenskaplike revolusies tot ' $n$ irriterende verleentheid of 'on-sin' gedegradeer en die status van hierdie vorm van kennis is nou 'om niks te verduidelik' nie. Net so het die sentrale posisie wat die mens vroeër in nadenke oor die kosmos ingeneem het, radikaal verskuif. En saam met hierdie antropologiese verskuiwing het 'n Godsverskuiwing in baie Westerse lande plaasgevind: God is eenvoudig heeltemal uit die kosmologiese prentjie uitgeskuif! Laasgenoemde verskuiwing het ingehou die volledige verlies van enige kosmiese doelmatigheid. Die kritiese vraag is of al die veralgemenende stellings wat ek hier aanbied, inderdaad begrond kan word? Dit is hierdie vraag wat na 'n dieper ondersoek vra en wat 'n belangrike onderskeid tussen amptelike en alternatiewe stories teweegbring. Eersgenoemde dra die karakter van populêre stories. Hierdie stories neem dikwels 'n totaliserende karakter aan. Totalisering is 'n baie spesifieke 'post-moderne' fenomeen waarin konseptualisering in die besonder geproblematiseer

28.Die oorspronklike formulering kom van Keith Ward (2006:19). Ek het sy verwysing na Tony Blair in sy formulering net kontekstualiserend met Nelson Mandela vervang. In die uiteensetting van die 'wetenskaplike revolusies' maak ek met erkenning gebruik van die basiese struktuur van Ward se argument in sy Pascal's Fire (2006).

29. Met hierdie sterk veralgemenende opmerking wil ek net die volgende punt maak: Juis as gevolg van die uiters suksesvolle tegnologiese ontwikkelinge (van daar die begrip 'materialistiese gemak') wat op die natuurwetenskaplike revolusies gevolg het, het verskeie natuurwetenskaplike rigtings (en hulle metodes) ongekende sukses en invloed geniet! My opmerking geld egter nie ongekwalifiseerd ten sukses en invloed geniet! My opmerking geld egter nie ongekwalifiseerd ten
opsigte van die geheel van die omvangryke spektrum van natuurwetenskaplike vakgebiede nie. 
word.$^{30}$ Dit behels die ingrypende insig dat ons, wanneer ons ons werklikheid konseptualiseer, die werklikheid dikwels baie groot geweld aandoen met dit wat ons in ons konsepte tot uitdrukking wil bring en vasvang. Meer dikwels gee hierdie vasvang en tot uitdrukking bring van ons werklikhede in ons konsepte eerder aanleiding tot manipulasie, beheersing en vergryp. Om die werklikheid dus as 't ware neer of vas te pen, is om dikwels te meen dat ek hierdie werklikheid in my greep het. Anders gesê: Dit is om hierdie werklikheid in te perk of in te forseer in die klinkers en konsonante waarmee dit tot uitdrukking kom en om sodoende die werklikheid geweld aan te doen. ${ }^{31}$ Vanuit hierdie insig as waarskuwing kyk ek vervolgens na die wetenskaplike revolusies wat plaasgevind het en wat diepgaande verskuiwinge in ons verstaan van die antropologie meegebring het.

\section{Die verskuiwinge ná Kopernikus en Galileo}

Die bydraes van Kopernikus (1473-1543) en Galileo Galilei (1564-1642) word gemaklik as die grondslag vir die oorlog tussen die natuurwetenskap en die geloof beskou, as die stryd tussen die perspektiewe 'sferiese aarde' en 'plat aarde' wat 'n sogenaamde de-antropologiseerde verstaan van die kosmos teweeggebring het. Hulle bydraes sou dan - in die woorde van die Ierse filosoof en Christelike apologeet Conor Cunningham (2010:282) - die groot oorwinning van die moderne denke oor die 'pokey piety of the religious ignoramus' bewerkstellig het (Cunningham 2010:282). In sy insiggewende Darwin's Pious Idea noem hy dit kortweg: '(C)omplete bunkum'. Volgens Cunningham het dit die amptelike storie geword. As amptelike storie het dit die brood en botter geword van diegene (soos onder ander die 'Nuwe Ateïsme'!) wat juis daarop uit is om die konflikpotensiaal van die verhouding tussen die natuurwetenskappe en die religie of teologie aan te hits (vgl. Cunningham 2010:282). Cunningham wys daarop dat antieke denkers soos Aristoteles, Erastosthenes en Ptolemeus almal hulle sterrekundige uitgangspunte geneem het vanuit die oortuiging dat die aarde rond was. So ook sou die kerkvaders vanaf Augustinus tot by Thomas Aquinas, wat geglo het dat die aarde sferies was, uiters verlig gewees het om te hoor dat die mens nie meer in die sentrum van die kosmos staan nie! Wat wel vanuithulle(Kopernikus en Galilei) bydraes voortgespruit het - as alternatiewe storie - is die hersiening deur die meeste tradisionele geloofsgroeperings van hulle foutiewe oortuiginge aangaande die aard van die fisiese kosmos en om letterlike interpretasies van die Bybel te bevraagteken (dit is, om Bybelse literalisme aan te spreek). Verder is hulle deur die ontwikkelings gedwing om ter harte te neem dat die mens nie die enigste of selfs belangrikste besorgdheid van God in die skepping is nie. Die oorlog wat wel ontketen is, was veel eerder - in die woorde van die Britse teoloog Keith Ward - te verstane as 'n 'struggle between competing scientific theories' (Ward 2006:108). Sommige

30. Kyk veral na die werk van James Smith (2002). Hy merk op: 'This concern regarding the violence of concepts is a distinctly postmodern matter, in the simple sense that it is only a "modern" concept which makes claims to totalization' (Smith 2002:4).

31.Die begrip 'totalitarisme' is bekend in politieke kringe waar dit gebruik word vir die aanduiding van regerings wat volledige beheer oor ' $n$ samelewing uitoefen en alle fasette daarvan wil beheer. Die begrip word hier egter gebruik as' $n$ aanduiding vir' $n$ onaanvaarbare wyse om in taal met die werklikheid om te gaan waarin on meen dat ons daardeur die werklikheid volledig in ons greep kry en beheer. van hierdie kompeterende natuurwetenskaplike teorieë wou hulle eie ideologiese standpuntinnames bevorder (so byvoorbeeld die ateïsme), naamlik'n pessimistiese beskouing dat die mens slegs maar 'n onbelangrike deel uitmaak van 'n onmeetbaar groot doellose kosmos wat onpersoonlik, bloot toevallig en vir uitwissing bestem is (vgl. Ward 2006:22; vgl. Haught 2008; vgl. Cunningham 2010). In hierdie ideologiese standpuntinname kan duidelik 'n hermeneutiek van geweld opgemerk word (d.w.s. totalisering) wat in die hieropvolgende natuurwetenskaplike verskuiwing na Newton eenvoudig as deel van die sogenaamde amptelike storie verder geneem is.

\section{Die verskuiwing ná Newton}

In sy baie interessante Pascal's Fire argumenteer Ward (2006:25 e.v., 108 e.v.) dat Newton se Principia Mathematica (1687) eintlik misbruik word om 'n materialistiese en deterministiese wêreldbeskouing te ondersteun. Die natuur sou hiervolgens aan absolute, nie-buigsame, alles-verduidelikende en onverbreekbare natuurwette ondergeskik wees. Dit maak van die kosmos 'n statiese kosmos waarin die natuur - as 'n onpersoonlike masjien volledig ooreenkomstig die algemene natuurwette werk. Impliseer dit - vra Ward (2006:27 e.v.) - dat die hele kosmos in terme van die masjienmetafoor verstaan moet word? So 'n wêreldbeskouing word dan gebruik (lees: misbruik!) om te impliseer dat daar onder andere geen doelmatigheid in die natuur is nie. En in die volgstroom van hierdie misbruik ${ }^{32}$ volg spontaan die oortuiging van 'n natuurlike verklaring van alles! Dit was beslis nie Newton se eie standpunt gewees nie. Newton was daarvan oortuig dat die wetenskap nie in staat is om die 'laaste' vrae oor die aard van die kosmos te beantwoord nie. Wat wel in die volgstroom van Newton se wetenskaplike bydrae lê - as alternatiewe storie - is 'n verstaan van die natuur as ontwikkelende sisteem, 'n veel indringender en effektiewer wyse om na oorsaaklikheid te kyk, 'n veel dieper verstaan van menslike ingryping in die natuur om dit te verbeter ten einde die moreel-neutrale natuurwette te gebruik om menslike lewe te verbeter! ${ }^{33}$ In 'n positiewe waardering van hierdie verskuiwing kan ek dit soos volg stel: Dit is merkwaardig en onverwags dat die natuur volgens wette so presies en so voorspelbaar funksioneer dat dit in wiskundige formules vasgevang kon word. En nog meer belowend en fassinerend is dat die natuur verstaanbaar ('intelligible') is en dat die mens ' $n$ baie kreatiewer en verantwoordeliker rol in die verbetering daarvan kan speel. Menswees hoef nie as 'slagoffer-wees' van materie verstaan te word nie. Stel hierteenoor die amptelike storie wat in die naam van Newton as die wetenskaplike bydrae van Newton (en daarna in die ontwikkeling en verstaan van onder andere elektromagnetisme, atoomstrukture, kernkrag, ook bewussyn!) verkondig word, naamlik dat materie al is wat

32.Ward (2006:108) stel hierdie misbruik duidelik: "It does not at all follow from his discovery that there are general laws of interaction between those physical entities whose nature can be specified quantitatively. The materialist worldview is not even implied by the hard science.'

33.Ward (2006:39) stel dit so: 'It looks as though the history of the cosmos is the story of a development from a primitive state of extreme simplicity and unconsciousness to a state in which highly organised complexity, consciousness and self-direction exists.' 
saak maak, dat die kosmos geen inherente waarde het nie, dat die kosmos volledig self-organiserend en deterministies bepaald is. Indien God - sou ek wou byvoeg tot die amptelike storie - tot net voor Newton nog werk gehad het, was God nou volledig werkloos! Totalisering par excellence! In die historiese konteks van hierdie vooropgestelde amptelike storie, volg Darwin se bydrae.

\section{Die verskuiwing ná Darwin}

In die lig van die voorafgaande uiteensetting is dit waarskynlik meer insiggewend om eers aan die amptelike storie oor Darwin aandag te skenk. Dit lui soos volg: Die wetenskaplike revolusie wat Kopernikus en Galileo begin en Newton voortgesit het, het Darwin kom afhandel (vgl. Cunningham 2010:3 e.v., 136). Na Darwin is al die los natuurlike rafels nou styf vasgeknoop. Die laaste vestingmuur van die menslike optimisme is omgestoot. Darwin se bydrae het 'n volledige natuurlike of fisikalistiese verstaan van die kosmos Darwin moontlik gemaak. Sy evolusionêre benaderingswyse was 'n kragtige verduideliking oor hoe kompleksiteit en ontwerp deur natuurlike prosesse kon ontwikkel. Selfs al is hierdie afhandeling eintlik eers later voltrek deur die molekulêre biologie en die genetika wat gedetailleerde chemiese inhoud aan Darwin se vae beskrywing 'descent with modification' (Ward 2006:51) gegee het, word hierdie hele ontwikkeling in die begrip 'Darwinisme' vasgevang. Dit is Darwinisme wat - volgens die ateïstiese interpretasie hiervan - nou sonder enige vrees vir teenspraak menswees se toevalligheid bevestig het. Menswees is die ongelukkige produk ('freakish accident') van miljoene kopieërfoute in die DNS. Homo sapiens bestaan slegs omdat dit alle teenstanders uitgewis het. Daar bestaan ook geen goeie redes vir hierdie spesie se oorlewing nie, want hulle oordrewe aggressiwiteit sal uiteindelik ook tot hulle eie ondergang lei (vgl. Ward 2006:52). Hierop volg dan verdere goeie voorbeelde van totaliserende denke: die kosmos bestaan beslis nou sonder enige doel, mense bestaan per ongeluk op grond van evolusie, alles is bestem om in die entropiese dood van die kosmos tot 'n einde te kom. Is daar teenoor hierdie amptelike storie 'n alternatiewe storie? Daar is.

Die alternatiewe storie is 'n opwindende en uitdagende storie wat vertel van veel groter kontinuïteit tussen mens en natuur, van 'n veel kleiner ontologiese verskil tussen mens en dier, van menswees as uiters gesofistikeerd maar terselfdertyd baie afhanklik en weerloos (vgl. Cunnnigham 2010:167 e.v.). In die alternatiewe storie kom nie soseer die 'hoe' van menswees in fokus nie, maar die 'wat' (vgl. Cunningham 2010:172). Ek keer egter terug na die amptelike storie, want hier eindig dit nog steeds nie. Een verdere ingrypende verskuiwing het nog meer oppervlakkige skietgoed aan die voorstanders hiervan verleen. Dit is die verskuiwing ná Einstein.

\section{Die verskuiwing ná Einstein tot by die kwantumfisika}

Die verskuiwing wat met die werksaamheid van die vader van die modern fisika, Albert Einstein (1879-1955) en sy relativiteitsteorie begin het, kom vandag die sterkste in die sogenaamde 'nuwe Fisika' na vore, dit wil sê, die kwantumteorie-fisika. Hierin word die nuwe merkwaardige eienaardigheid van die struktuur van ons fisiese werklikheid. Hierin word wegbeweeg van 'n ou materialistiese perspektief waarin die kosmos of universum atomisties verstaan is, na 'n nuwe verstaan van die fisiese werklikheid van elektrone wat nie meer in vaste bane soos klein planete om atoomkerne wentel nie, maar as golwe wat in partikels inplof sodra dit waargeneem of gemeet word! Net enkele opmerkinge oor ons verbysterende fisiese werklikheid: Daar is blykbaar 'n radikale verskil tussen wat die fisiese werklikheid is wanneer dit waargeneem word en wanneer dit nie in allerlei afmetinge vasgevang word nie! Golwe word byvoorbeeld nie waargeneem nie, maar wel partikels. Is beide werklik? Of is daar ' $n$ 'verborge' werklikheid? Wat is die verhouding hiervan tot die waarnemer en sy of haar bewussyn? Is daar vorme van kousaliteit wat nie-deterministies is en wat ' $n$ oop toekoms impliseer? Hoe moet kwantum-verstrengeling verstaan word, dit wil sê, die kosmos as omvangryke netwerk van interaktiewe partikels wat in een enkele kwantumsisteem saamgebind word?

Oor hierdie en baie ander vrae vind ons by natuurwetenskaplikes baie uiteenlopende antwoorde. Het ons te make met ' $n$ volledige omkering van die materialisme? Indien weliswaar nie 'n volledige omkering nie, dan ten minste ' $n$ diepgaande hersiening! Die vroeëre atomistiese materialisme is dood. Wat in my argument hier van besondere belang is, het met die plek en rol van bewussyn te make. In uiteenlopende kontemporêre diskoerse (byvoorbeeld die neurowetenskappe) blyk die fundamentele en onmisbare plek en rol van bewussyn in die voorstellinge van hoe die werklikheid daar sou uitsien. Hierdie 'hoe' van die fisiese werklikheid - dit is, die elektrone en atome waaruit die fisiese werklikheid waarskynlik bestaan - bestaan slegs in verhouding tot die menslike waarnemer. Cunningham (2010:159) verwys in dié verband na die treffende woorde van Georg Wald: 'A physicist is the atom's way of knowing about atoms.'

Hoe hou dit nou met my vertel van die sogenaamde amptelike en alternatiewe stories verband? Net soos die amptelike stories van Galileo, Newton en Darwin ideologiese vergrype verteenwoordig, net so vind ons in die amptelike storie van die Nuwe Fisika voortgesette en verder verdiepende ideologiese vergrype. Ja, God is oorbodig. Ons het God nie eers meer as hipotese nodig nie. Sterker nog: Dis nou finaal: God bestaan nie. Die kosmos is self-organiserend en sonder enige doel. Homo sapiens is toe inderdaad 'n toevallige neweproduk, en bewussyn kan volledig verduidelik word. Oor hierdie - en ander - vergrype voer Cunningham $(2010: 176,269)$ aan dat dit nie die hemel is wat bedreig word nie, maar die aarde! Hoe sou die alternatiewe storie lui?

Hierin is die natuurwetenskappe, en veral die Nuwe Fisika, beslis nie die laaste poort tot waarheid nie, nog minder alleen (amptelike!) verteenwoordiger van die storie wat die kosmos te diepste verduidelik. Die alternatiewe storie 
sluit doelmatigheid, waardes en persoonlike ervaringe in. Dit ontsluit 'n perspektief op die kosmos as ontluikend ('emerging'). Ons praat weliswaar van 'n verstrengelde werklikheid, maar dan as 'n organiese eenheid. Ward (2006) vat hierdie alternatiewe storie - wat ek hier in twee langerige aanhalings wil weergee - goed saam wanneer hy ten opsigte van die kosmos en menswees die volgende sê:

The cosmos is a complex interplay of change, freedom, intelligibility and necessity. The observed universe is a phenomenal appearance of an underlying intelligible realm of potentialities, which are continually being actualised in new ways, unpredictable in detail yet constrained by the finely tuned values of the universe's basic constants and forces and by past interactions of its entangled properties. As the cosmos grows more integrated and complex, it generates beings that can understand and to some extent shape their own future, and this trajectory of growth points towards the genesis of self-aware and self-directing minds as the ideal outcome of the universe's long journey of self-realisation. ... Being human and human consciousness is seen as an integral part of this universe. Being human not as the only goal for the sake of which the whole universe exists. Human consciousness not as an intrusion of the spiritual into the material. A story in which finite consciousness is a product - not of a deterministic and mechanistic clockwork universe - but of a universe in which both creative spontaneity and holistic forms of causality play an important part. (bl. 6, 7)

In beide hierdie aanhalinge van Ward is die trant en wyse waarop die kosmos en menswees verwoord word veel anders as dit wat ons in die amptelike storie vind. Dit is teen hierdie verbysterende en steeds ontluikende agtergrond van die uiteenlopende implikasies van amptelike stories en alternatiewe stories waarin ek na die kern van die argument rakende die vriendskap met Darwin wil terugkeer. Ek wil daarna terugkeer met toespitsing op die verwysing na die 'domestisering' van God aan die begin van hierdie artikel as saamlopende problematiek.

\section{Evolusie en die ontdomestisering van God}

Net soos wat ' $n$ fisikus die wyse is waarop ' $n$ atoom ' $n$ atoom ken (Georg Wald) en 'n bioloog die wyse is waarop 'n sel 'n sel ken, net so is die mens die wyse waarop die lewe lewe ken. Inderdaad verwelkom die lewe interpretasies! Dit nooi ons uit om dit te interpreteer. Dit is 'n uitnodiging wat ons op baie uiteenlopende wyses vanuit ons aprioriese lewensen wêreldbeskouinge aanvaar. ${ }^{34}$ En in die interpretasieproses konstrueer ons verskillende grense. Die evolusionêre biologie het 'n ongekende spektrum nuwe stimuli vir nadenke oor die oorsprong van lewe, die lewe self en wydlopende diversiteit losgelaat. Op dieselfde wyse het die ander natuurwetenskaplike revolusies ons uitgenooi om verder en dieper oor 'lewe' na te dink. Die oop uitnodiging tot interpretasies van lewe word egter gemaklik misbruik soos wat ons aan die een kant in die bio-fundamentalisme oor die nie-bestaan van God en aan die ander kant in die

34. Hierdie aanvaarding van die oop uitnodiging gaan wel vir my rigtinggewend gepaard met die baie gepaste woorde van die Deense teoloog Niels Gregersen (2001:197) wanneer hy stel: .... (M)etaphysical options are open for discussion, facts are not open for negotiation.' Dit beteken eenvoudig - as voorbeeld - dat ons facts are not open for negotiation.' Dit beteken eenvoudig - as voorbeeld - dat ons
biologiese oorsprong en beperkinge vasstaan en dat ons in die lig daarvan opnuut biologiese oorsprong en beperkinge vasstaan en dat ons in die lig daarvan op
moet dink oor ons geloofuitsprake wat in die lig daarvan anders kan uitsien. sogenaamde skeppingsmatige bewyse van God in die kreasionistiese benaderinge en IO kan sien. Beide - aan weerskante van hierdie spektrum - is van dieselfde (denk) stoffasie! Net so min as wat die sogenaamde aanvaarding van evolusie dit vir 'n persoon sou moontlik maak om op grond van die verwerping (so Dawkins) 'n vervulde ateïs te word, net so min gaan die verwerping of ignorering van evolusie die Godsbestaan bewys of van 'n persoon 'n Godsgelowige maak (so die Kreasioniste). Juis laasgenoemde poging om dit wel te doen en die onberekenbare skade wat dit berokken, wil ek ten slotte aanspreek.

Om 'n vriendskap met Darwin te sluit, is om as teoloog met die beste wetenskap in die biologie erns te mak. Die beste wetenskap in die biologie word vandag vanuit evolusionêre perspektiewe benader. Die teologiese nadenke wat die ononderhandelbare belydenis van God as skepper en Homo sapiens as God se handewerk as vertrekpunt neem, dwing die Christen-teoloog tot radikaal hersienende nadenke oor die wyse waarop God alles is (dus teenwoordig en betrokke by God se skepping) en beslis nie niks is nie. ${ }^{35}$ Hierdie 'alles-God' word deur die Bybelse boodskap beskryf as 'n heilige, diep onpeilbare God wat met die mens - as God se handewerk - in verhouding staan. Radikaal hersienende teologiese nadenke hieroor wil ek teologies-evolusionêre re-konseptualisering (TE-RK) noem. Dit is TE-RK wat vir Dawkins trompop kan loop wanneer hy sê dat hy geen verduideliking vir komplekse biologiese ontwerp kan gee nie, maar dat hy weet dat God nie 'n goeie verduideliking is nie. Op so 'n argument kan TE-RK hom antwoord en 'n verduideliking gee! TE-RK kan 'n verwelkomende verduideliking gee oor die 'alles-God' en 'die-alles-God-in-verhouding-met-diemens', 'n verduideliking wat terselfdertyd die waarskuwing vanuit onder andere natuurwetenskaplike kringe (veral ook filosofiese kringe) ernstig neem dat religieuse nadenke dikwels negatief gevaarlik en vernietigend kan wees en beslis nie 'onskadelike nonsens' (hierin is Dawkins reg) is nie. TERK kan 'n verwoording bied waarin die teologiese nadenke haar geloofwaardige plek sal (leer) ken (Ellis 2006) en sal raaksien hoe sy dikwels haar (ken)hand skeppingsmatig in die eiesinnige opeis van God vir ons en my religieuse oortuiginge oorspeel. Dit is hierdie 'opeis van God vir ons' wat ek die domestisering van God noem. Hierin neem ek die waarskuwing van die Duits-Switserse teoloog Karl Barth ernstig op. Alhoewel hy in 'n totaal ander teologies konteks en met 'n volledig ander uitkoms voor 'n dag gekom het, was dit juis hy wat die Duitse kerk gewys het op die gevaar van die domestisering van God, destyds verwoord as die gevaar wat in die Kulturprotestantismus ingebed lê. ${ }^{36}$ Dit is die onnadenkende tuismaak van ons Godsoortuiginge in ons tradisie, ons vooropgestelde idees, ons voorwaardes

35.Ten opsigte van ons Godsverstaan stel Van Huyssteen (2011:121-2) Darwin se bydrae soos volg: 'Op briljante wyse het Darwin ... met een teorie twée onaanvaarbare Godsidees van die tafel gevee: die veraf ontwerper God van die deïsme, asook die uiters problematiese "God-van-die-gapings" wat gewoonlik derlef het daar waar gapings in ons wetenskapskennis was, net om later uitgestoot te word soos ons kennis verder ontwikkel.'

36. Dit verteenwoordig 'n geestesstroming in die Duitse samelewing wat veral ná 1860 gewild was. Die Duitse etiese teoloog Albrecht Ritcshl word as die vader hiervan bestempel. In kort sou hierdie misloopte etiese teologie uiteindelik saamgevat kon word in die woorde: Om 'n goeie Duitser te wees, is om 'n goeie Christen te wees. Dalk beter gestel: Godsdienstige en kulturele waardes is met mekaar vereenselwig. 
wat ons graag stel oor hoe God Godself dan sou openbaar het - en nie! Dit is niks anders as 'n volslae totalitêre greep op God nie. Ek meen dat TE-RK juis hierdie gevaar van domestisering radikaal (nuut) aanspreek. ${ }^{37}$ TE-RK spreek die gevaar so radikaal aan dat dit die hele (alternatiewe) verhaal van lewe op aarde in 'n totaal ander lig plaas waarin ons nie ons biologiese oorsprong van ons groter kosmiese konteks (byvoorbeeld menslike bestaan op grond van koolstof) en van die geskiedenis van die kosmos (byvoorbeeld die 'verfyning' van die universum) kan losmaak nie. Ons word eenvoudig tot 'n meer omvattende teleologie gedwing. Ons word tot ontdomestiserende denke oor God gedwing. Positief gestel: Ons word gedwing om opnuut en verrassend met die grootheid en die onpeilbare diepte van God gekonfronteer te word. Ons kan selfs dieper delf: Ons word gedwing om met God se prysenswaardigheid gekonfronteer te word. ${ }^{38}$ Iets hiervan vind ek in McGrath (2009) se verwysing na die besondere woorde van Charles Kingsley wat in 'n lesing in 1871die volgende gesê het:

We knew of old that God was so wise that He could make all things; but behold, He is so much wiser than even that, that He could make all things make themselves. (bl. 210)

So kies TE-RK allerlei nuwe opwindende teologiese koerse in die nadenke oor skepping, God, menswees, genade, verlossing en nog meer, ${ }^{39}$ om maar enkele opwindende koerse aan te dui. Skepping verwys nou nie net meer na 'n sogenaamde eenmalig, afgehandelde oer-skeppingsdaad van God nie, maar veel eerder na 'n voortgaande skepping as ontluikende skepping (die ontluikende of ontwikkelende kosmos), na 'n 'kreunende skepping', 'n onvoltooide skepping, ${ }^{40}$ 'n onklaar kosmos of universum wat nie hier en nou die status van 'voltooide perfeksie' het nie (Haught). En as onvoltooide, nie-perfekte universum bring dit ons by 'n volledig ander verstaan van die voorkoms van boosheid, dood en pyn, lyding en sonde. Ons is by wyse van evolusionêre spreke - in verwysing na die skeppingsverhale van Genesis - op die sesde dag van die skepping geskape. Die goedheid van God se skepping is te verstane as die ontluikende vermoë van die skepping om aan waardes soos skoonheid, diversiteit, kompleksiteit gestalte te gee (Southgate). Ook is

37.So byvoorbeeld in $n$ teologie van die natuur nie te verwar met natuurlike teologie nieen verskillende evolusionêre teologieë (kyk byvoorbeeld na die bydraes van Philip Clayton, Niels Gregersen, John Haught, Ted Peters, Jack Mahoney, John Polkinghorne, Holmes Rolston III,en Michael Ruse).

38. My betoog hier neem die vroeër aangehaalde woorde van die bioloog David Hull ernstig op wat in verwysing na sy ervaring op die Galapagos-eiland gevra het: Nou watter soort God leer ons hier in die skepping ken, en dan byvoeg dat dit beslis nie een is tot wie ons sal bid nie. Hierop sou gelowiges onomwonde wou stel: Dit is tot 'n prysenswaardige God wat ons bid! En dit is dieselfde God wat die hemel en aarde geskape het.

39.Begeleidend tot hierdie nuwe teologiese koerse is die wete dat ons nie anders kan as om by die interdissiplinêre gesprekstafel oor die oorsprong van kennis aan te sit nie. Aan hierdie tafel is evolusionêre epistemologie die selfaangewese gashee of seremoniemeester. Waarom? Die kontemporêre kosmologie dring eksplisie aan daarop dat die waarneembare universum as 'n enkele kenobjek hanteer moet word, dit wil sê dat menslike kennis geïntegreer of omvattend benader moet word. Ons kan dus nie meer met 'npluraliteit van verskillende, gefragmenteerde of nieverbandhoudende vorme van kennis of kenaansprake tevrede wees nie. Indien ons meen dat ons in ons teologiese uitsprake op 'n geloofwaardige wyse kenaansprake wil maak, sal ons die aandrang op geïntegreerde kennis moet ernstig neem sodat ons nie onsself in 'n esoteriese wêreld van privaat, geïsoleerde kenaansprake onttrek nie.

40. Hierdie formulering is ontleen aan Southgate (2008:17) in sy hantering van die teks van Romeine 8:19-22. Hiermee wil hy geensins te kenne gee dat Paulus een of ander evolusionêre bewussyn sou gehad het nie. Hy wil eerder beklemtoon dat, waar Paulus in terme van die verganglikheid van die skepping as gevolg van die waar Paulus in terme van die verganglikheid van die skepping as gevolg van die
sondeval gedink het, ons van hierdie uitgangspunt en van 'n oorspronklike paradys moet afstand doen. die skepping goed omdat dit aan God behoort! So ook word ons Godsverstaan diep en breed verryk. Hy is die lewende God as selfprysgewende en kenotiese God, as mee-lydende en weerlose God (Haught; Gregersen), as die Een wat aan die kruis die prys vir lyding in die wêreld betaal en hierdeur vir die pyn van die skepping verantwoordelikheid neem. Die kruis is ' $n$ voorbeeld by uitnemendheid van goddelike meelewing en die opstanding is ' $n$ voorbeeld van die neem van die verantwoordelikheid vir die transformasie van die skepping (Gregersen). Vir die antropologie - wat hier die fokus is - is daar net sulke verreikende implikasies. Menswees as imago Dei word op die eeuelange ontluiking van menslikheid in totaliteit betrek (Van Huyssteen); die tradisionele skerp ontologiese diskontinuïteit tussen mens en dier word opgehef. Ons kenvermoëns dra die stempel en beperkinge van ons biologiese oorsprong ${ }^{41}$ en die evolusionêre prosesse (in die sin van 'propensity') van kompleksifisering bring ingrypende hersienings mee van die mens as bewussynmatige en waarnemende wese (Cunningham; Southgate). Dit geld byvoorbeeld vir die dood as termodinamiese noodwendigheid, pyn as prys wat betaal moet word vir ' $n$ uiters gesofistikeerde en hoogs sensitiewe senuweestelsel, die 'hardheid' van die lewe as kreuning in die voortgaande ontluiking van lewe en die natuurlikheid van religie ${ }^{42}-$ om maar net ' $n$ aantal dimensies te lys.

Die voorbeelde hierbo is slegs enkele voorbeelde van 'n teologies-evolusionêrende re-konseptualisering. Wat duidelik hieruit na vore kom, is dat die teologiese verhaal ná Darwin - in vriendskap - ingrypend uitgebrei is. Dit word duidelik dat ons alternatiewe teologiese verhaal oor die alles-God se meelewing en betrokkenheid kosmies uitgebrei moet word om die 'pynlike kreuning' van die universum te ontsluit, die 'pynlike kreuning' as die gegewe evolusionêre geweefdheid van die skepping. Dit word duidelik dat ons alternatiewe teologiese verhaal van menswees as imago Dei uitgebrei moet word. Dit moet uitgebrei word met die verdiskontering en verkonkretisering van ons biologiese oorsprong en die noodwendige fisiese stempels (pyn, dood, lyding) wat dit vir en in ons menslike bestaan meebring. Dit is - in kort - om op ' $n$ nuwe opwindende biologiesgestempelde wyse in ons Christelike ontwerpe van die antropologie erns te maak met die gebedswoorde van die vytiende-eeuse Duitse filosoof-teoloog, regsgeleerde en wiskundige, Nicholas van Cusa: 'Here, hoe kan U uself aan my gee indien $U$ nie eers my aan myself gegee het nie?' (vgl. Haught 2008:43). Ons taak is om hierdie 'aan myself gegee'

41.Intelligensie het ontluik ('emerged') as 'n besondere menslike instrumentaliteit vir menslike oorlewing en samewerking. Dieselfde geld ook vir waardes, verwagtinge of doelstellinge en die vermoë ('propensity') tot rasionele kennis. Van Huyssteen verwys na hierdie vermoë tot rasionele kennis in die woorde van Stephen Mithen as kognitiewe vloeibaarheid ('cognitive fluidity'), dit wil sê, ons kapasiteit tot verbeelding, simboliese denke en kreatiwiteit (Van Huyssteen 2006:19, 42, 193).

42.Ons religieuse nadenke as kulturele produk wat deur ons biologiese oorsprong vormgewend beïnvloed is, word egter nie volledig daardeur bepaal nie. Keith Ward het al by geleentheid daarop gewys dat religieuse (en so ook teologiese) nadenke ons lei na vlakke van verduideliking ('explanation') wat 'bo' sigself uitgaan. Indien ons gene nie volledig ons kultuur en rasionele vermoëns bepaal nie, dan is dit redelik om te verwag dat ons gene, ons kultuur en ons rasionele vermoëns ook redelik om te verwag dat ons gene, ons kultuur en ons rasionele vermoens ook
nie volledig ons blywende en oorredende behoefte aan metafisika bepaal nie, en no volledig ons blywende en oorredende behoefte aan metafisika bepaal nie, en so uiteindelik ook nie lewenstransformerende religieuse geloof nie (Van Huyssteen en teologiese nadenke moontlik om verby ('beyond') die sogenaamde nou opsie en teologiese nadenke moontlik om verby ('beyond') die sogenaamde nou opsie
van of/of te beweeg, byvoorbeeld die eng opsie van natuurlikof bonatuurlik (vgl. Cunningham 2010:408 e.v.). 
evolusionêr nuut te bedink ná Darwin. Ons moet dit ter wille van die prysenswaardigheid van ons God in vriendskap met Darwin en op ontdomestiserende wyse antropologies nuut bedink.

\section{Erkenning \\ Mededingende belange}

Die outeur verklaar dat hy geen finansiële of persoonlike verbintenis het met enige party wat hom nadelig kon beïnvloed in die skryf van hierdie artikel.

\section{Literatuurverwysings}

Antonites, A., 2010, Evolution: Fact or theory?, CreateSpace, Scouts Valley.

Clayton, P., 2005, 'Theology and the physical sciences', in D.F. Ford (ed.), The modern theologians, 3rd edn., pp. 342-356, Blackwell, Oxford.

Cunningham, C., 2010, Darwin's pious idea, Eerdmans, Cambridge.

Darwin, C., [1859] 1884, On the origin of species, Murray, London.

Darwin, C., 1871, Descent of man, Murray, London.

Dennett, D., 1995, Darwin's dangerous idea: Evolution and the meanings of life, Simon \& Schuster, New York. PMid:7625156

Dobzhansky, T., 1973, 'Nothing in biology makes sense except in the light of evolution', American Biology Teacher 35, 125-129. http://dx.doi.org/10.2307/4444260

Ellis, G., 2006, 'Why the science and religion dialogue matters', in F. Watts \& K. Dutton (eds.), Voices from the International Society for Science and Religion, pp. 3-25, Templeton Foundation Press, West Conshohocken. PMid:16542736

Gregersen, N.H. 2001, 'The cross of Christ in an evolutionary world', Dialog: A journal of Theology 40(3), 192-207.

Haught, J.F., 2008, God after Darwin, Westview Press, Boulder
McGrath, A., 2009, A fine-tuned universe, Westminster John Knox Press, Louisville.

Montgomery, D.R., 2012, 'The evolution of creationism', Geological Society of America Today 22(11), 4-9. http://dx.doi.org/10.1130/GSATG158A.1

Nürnberger, K., 2011, Regaining sanity for the earth, Xlibris, London.

Peters, T. \& Hewlett, M., 2007, Can you believe in God and evolution? A guide for the perplexed, Abingdon Press, Nashville.

Ruse, M., 2001, Can a Darwinian be a Christian? The relationship between science and religion, Cambridge University Press, Cambridge.

Smith, J.K.A., 2002, Speech and theology, Routledge, London

Southgate, C., 2008, The groaning of creation, Westminster John Knox Press, London.

Sterelny, K., 2009, 'Philosophy of evolutionary thought', in M. Ruse \& J. Travis (eds.) Evolution: The first four billion years, pp. 313-329, Harvard University Press, London.

Szerszynski, B., 2012, 'Life in the open air', unpublished presentation during the ESSSAT conference, Tartu, Estland, 27 April.

Van de Beek, B., 2005, Toeval of schepping? Scheppingsteologie in de context van het moderne denken, Kok, Kampen.

Van Huyssteen, W., 2006, Alone in the world?, Eerdmans, Grand Rapids. PMid:16645122

Van Huyssteen, W., 2007, 'A brief overview of a theologian's journey to interdisciplinarity', unpublished document.

Van Huyssteen, W., 2011, 'J Wentzel van Huyssteen in gesprek met Frits Gaum', in G. Claasen \& F. Gaum (reds.), God? Gesprekke oor die oorsprong en uiteinde van alles, bl. 113-132, Tafelberg, Kaapstad.

Veldsman, D.P., 2012a, 'With a little help from our friend! A systematic-theological appreciation of Bram van de Beek's theology of creation as contribution to the contemporary theology-science dialogue', Journal of Reformed Theology 22 979-814.

Veldsman, D.P., 2012b, 'Too many experiments, too little philosophical reflection, unpublished presentation during the 3rd Neuroscience Day of the University of Pretoria, South Africa.

Ward, K., 2006, Pascal's fire: Scientific faith and religious understanding, Oneworld Publications, Oxford.

Watts, F. \& Dutton, K. (eds.), 2006, Why the science and religion dialogue matters: Voices from the international society for science and religion, Templeton Foundation Press, Philadelphia. 